\title{
EFFECTS OF SPEED SINTERING ON MULTILAYERED MONOLITHIC ZIRCONIA
}

\section{ABSTRACT}

Objectives: In dentistry, different products are being developed in order to shorten the chairside but the interactions between these materials needs further investigations. This study aims to investigate the two different short time sintering protocols on monolithic multilayered zirconia's surface roughness (SR), translucency parameter (TP), and contrast ratio (CR).

Materials and Methods: 20 monolithic multilayer zirconia specimens were prepared with the dimension 10x10x1 mm and divided into two sintering groups (speed sintering group $30 \mathrm{~min}$ at $1510^{\circ} \mathrm{C}$, high speed sintering group $10 \mathrm{~min} 1580$ ${ }^{0} \mathrm{C}$ ) and SEM analyzed was performed. Surface roughness tests were performed by using profilometer and optical measurements were performed by using spectrophotometer. The data was statistically analyzed by using Wilcoxen test at the 0.05 probability level.

Results: Surface roughness and contrast ratio among groups were not statistically different. In all parts of monolithic multilayered zirconia, the difference of TP between sintering groups were statistically significant $(\mathrm{p}<.05)$. No obvious grain size difference was detected according to the SEM images.

Conclusions: High speed sintering parameters has promising effects on monolithic multilayered zirconia with combined acceptable optical properties. Because of their different content, different layers show different reactions in terms of contrast ratio and translucency parameters and these changes should be taken into account in treatment planning.

Key words: Zirconia, sintering, contrast ratio, translucency

\author{
*Mehmet Emre Coskun ${ }^{1}$ \\ D Fatih Sar1 $^{2}$
}

ORCID IDs of the authors:

M.E.C.0000-0002-2430-5170

F.S.0000-0002-4818-8562

1 Department of Prosthodontics, Faculty of Dentistry, Sivas Cumhuriyet University, Sivas, Turkey.

2 Department of Prosthodontics, Faculty of Dentistry, Gaziantep University, Gaziantep, Turkey.

Received : 08.01.2019 Accepted : 23.01.2019 


\section{INTRODUCTION}

The approved high flexural strength, fracture toughness, corrosion resistance, biocompatibility, and the chemical stability increase the acceptance and the demand of the zirconia over metal-ceramic restorations in prosthetic dentistry. ${ }^{1-4}$ Zirconia is widely used in most prosthetic rehabilitation scenario, the applications in prosthodontic scope are ranged from a single framework veneered with ceramic to the full arch monolithic restoration, from an implant body and the abutment to the screw retained implant supported full arch prosthesis. The most frequent problem of zirconia restorations is chipping, failure of the zirconia-ceramic bond strength $^{5}$, which was mentioned that the occurrence frequency is $13 \%$ after three years. ${ }^{6}$ Recently, full anatomic monolithic zirconia restorations are introduced to overcome the chipping issue ${ }^{7}$ with the advantages of the decreasing cost and production time, sufficient fracture toughness within the minimal invasive preparation depth $^{8-10}$ and ease of application. ${ }^{11}$ However, such restorations are not satisfactory for the rehabilitation of the anterior region because of the opacity of the zirconia. The enhancement of the crystalline content to improve the mechanical properties, deteriorate the optical properties owing to the discrepancies of the refractive index of multiple crystalline structure of zirconia. ${ }^{12}$

Making tooth like zirconia restorations, the major concern to mimic the natural appearance is to replicate the color of tooth. Two different methods are performed for coloring zirconia. The first attitude in order to obtain different shades of color is immersing the zirconia into colorant rare earth element chloride solution. This method is easy to perform, time saving, and useful for the frameworks which are veneered with ceramics however, two failings, irregular color distribution and different color regions after grinding for the modification of substructure due to the amount of infiltration depth. ${ }^{13}$ Furthermore, Tuncel et al. ${ }^{14}$ mentioned that the colorant solution increase the contrast ratio. The latter attitude to produce the different color zirconia is adding the metal oxides into the zirconia structure in manufacturing stage which alters the microstructure. Adding metal oxides to obtain o homogenous color distribution, increases the translucency. ${ }^{15}$ However, adding metal oxide is not the only determinant for the optical properties of the zirconia. Translucency, the amount of light passing through the material ${ }^{16}$, depends on the sintering parameters and the additives into the zirconia powders before pressing. ${ }^{17}$ Especially, surface roughness (SR), grain size, amount of crystallographic transformation (monolithic $\rightarrow$ tetragonal), density, pores within the structure are determined by sintering temperature and dwelling time. ${ }^{18}$

In sintering process, the pores between particles within the granular material decreased by atomic diffusion. ${ }^{19}$ The Increasing temperature and dwelling time of sintering process made the grain size larger and forms the zirconia much translucent. ${ }^{7}$ The common method of conventional sintering (CS) process is placing the samples into the furnace at room temperature and regulating the heat rate, holding temperature, holding time, and cooling rate according to the manufactures' instructions. However, only one sintering protocol is advised, but there are a lot of differences in terms of sintering protocols. For instance, unlike the routine process of $\mathrm{CS}$, in the novel sintering protocol [high-speed sintering protocol (HS)] the samples are placed into the furnace which have already reached the sintering temperature $\left(1580^{\circ} \mathrm{C}\right)$ and hold only for 10 minutes. For this reason, searching the interaction between optical properties of zirconia and sintering parameters is of great importance.

Optical properties are also depends on the surface texture ${ }^{20}$ which arranges the direction of light reflection; the rougher surface, the more scattered light reflection..$^{21}$ On the other hand, it is a complex issue and hard to clarify the relation between surface texture and light scattering.

Recently, multi-layer monolithic zirconia with the help of state of art furnace, along with a HSP, are more preferred over other prosthetic restorations in order to shorten the treatment time. However, there is no publication in the literature searching the effect of HSP on the optical properties of multi-layered monolithic zirconia. Until now, only the effect of HSP on flexural strength were investigated in literature and mentioned that the flexural strength was higher than $\mathrm{CS}^{22}$ 
Therefore, this in vitro study aimed to investigate the effect of speed and high-speed sintering protocols on surface roughness and translucency at all layers of monolithic multilayered zirconia. The tested hypotheses were that the decreased dwelling time with the increased temperature would (a) decrease on surface roughness and (b) improve optical properties, decrease the contrast ratio and increase the translucency parameter, at all layers of the multilayered zirconia.

\section{MATERIALS AND METHODS}

\section{Specimen preparation}

CAD-CAM-milled, square shape $(10 \mathrm{~mm} \times 10$ $\mathrm{mm}) 20$ specimens of $1 \mathrm{~mm}$ thickness were prepared from pre-shaded (A light) multi-layered monolithic zirconia (ML, Katana, Noritake, Japan). Specimens were divided into two groups according to the sintering parameters (n:10).

The high-speed sintering protocol (HS): The specimens were placed in a heated furnace inFire HTC Speed (Sirona, Bensheim, Germany) at 1580 ${ }^{0} \mathrm{C}$ for $10 \mathrm{~min}$ and take out for bench cooling immediately. The total sintering protocol with dwelling time is $10 \mathrm{~min}$.

The speed sintering protocol (SS): The specimens were placed into the furnice at room temperature and placed for $30 \mathrm{~min}$ at $1510{ }^{\circ} \mathrm{C}$ than cooled to $600{ }^{\circ} \mathrm{C}$ then bench cooling. All sintering protocols were performed in inFire HTC Speed (Sirona, Bensheim, Germany).

\section{Surface roughness test}

All specimens were cleaned ultrasonically with isopropanol for $5 \mathrm{~min}$ before surface roughness test. Tests were performed by using profilometer (Surftest SJ-301; Mitutoyo, Tokyo, Japan) with a travelling distance of $2 \mathrm{~mm}$ across the layers (enamel, transition, body) of the specimens. 6 measurements from each layer were used to determine the average $\mathrm{Ra}(\mu \mathrm{m})$ value.

\section{Optical Properties}

The specimens from all groups were optically analyzed by using spectrophotometer using D65 light (Easyshade advance; Vita Zahnfabrik, Badsackingen, Germany) according to the CIELab* scale for three times from each layer. Two different black (CIE L* $1.1 \mathrm{a}^{*}=13.8$ $\left.\mathrm{b}^{*}=52.2\right)$ and white $\left(\mathrm{CIEL}^{*}=17.6 \mathrm{a}^{*}=2.0 \mathrm{~b}^{*}=6.6\right)$ backgrounds were used for measurements. Increase in value means increase in translucency. The formula used for the translucency parameter (TP) calculation:

$\mathrm{TP}=\left[\left(\mathrm{L}_{\mathrm{B}}-\mathrm{L}_{\mathrm{W}}\right)^{2}+\left(\mathrm{a}_{\mathrm{B}}-\mathrm{a}_{\mathrm{W}}\right)^{2}+\left(\mathrm{b}_{\mathrm{B}}-\mathrm{b}_{\mathrm{W}}\right)^{2}\right]^{1 / 2}$

The contrast ratio (CR) measurements were performed using the formula:

$\mathrm{Y}_{\mathrm{B}} / \mathrm{Y}_{\mathrm{W}}$, where $\mathrm{Y}$ is: $[(\mathrm{L}+16) / 116]^{3}$ x 100

In all formulas the $\mathrm{B}$ represents the black background, while $\mathrm{W}$ represents white background. ${ }^{23}$ According to the $\mathrm{CR}$ value calculations ' 0 ' represent translucent and ' 1 ' is opaque.

\section{Statistical analysis}

The numerical data was checked for normal distribution using Shapiro-Wilk test and analyzed using Wilcoxen test by SPSS 22.0 statistic (SPSS Inc, Chicago, USA) at a significant level of $P<.05$.

\section{RESULTS}

The mean values of optical measurements and SR were depicted in Table 1 and Figure 1.

Table 1. The mean values and standard deviations of surface roughness, contrast ratio and translucency parameter.

\begin{tabular}{cc|ccc}
\multicolumn{2}{c}{ Groups } & Enamel & Transition & Body \\
\hline SR & HS & $0.64 \pm 0.13$ & $0.61 \pm 0.07$ & $0.55 \pm 0.09$ \\
SS & $\mathbf{0 . 6 1} \pm \mathbf{0 . 1}$ & $\mathbf{0 . 5 5} \pm \mathbf{0 . 1 5}$ & $\mathbf{0 . 5 7} \pm \mathbf{0 . 1 1}$ \\
& & & \\
CR & HS & $0.82 \pm 0.01$ & $0.80 \pm 0.02$ & $0.82 \pm 0.03$ \\
SS & $\mathbf{0 . 8 3} \pm \mathbf{0 . 0 2}$ & $\mathbf{0 . 8 3} \pm \mathbf{0 . 0 2}$ & $\mathbf{0 . 8 1} \pm \mathbf{0 . 0 2}$ \\
& & & \\
TP & HS & $9.59 \pm 0.67^{\mathrm{b}}$ & $9.7 \pm 1.05^{\mathrm{e}}$ & $9.89 \pm 1.11^{\mathrm{g}}$ \\
SS & $\mathbf{3 . 0 9} \pm \mathbf{0 . 1 1}$ & $\mathbf{3 . 1} \pm \mathbf{0 . 1 7 ^ { \mathrm { b } }}$ & $\mathbf{3 . 1 4} \pm \mathbf{0 . 1 8 ^ { \mathrm { g } }}$ \\
\hline
\end{tabular}

* Surface roughness (SR); contrast ratio (CR); translucency parameter (TP); high speed sintering (HS); speed sintering (SS). The values with same superscript means statistically significant difference $(p<.05$.) 


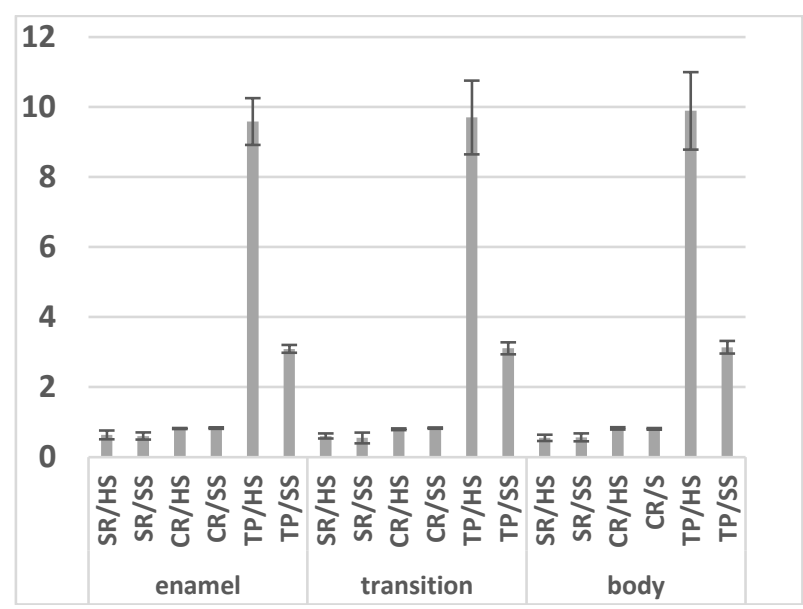

Figure 1. The mean values and standard deviations of obtained optical properties, and surface roughness. Translucency parameter (TP); contrast ratio (CR); surface roughness (SR); high speed (HS); super speed (SS).

As it was mentioned, SR didn't show significant difference at any layer between sintering groups. The mean CR showed no significant difference on any part of the zirconia in all sintering groups. The only significant difference was obtained on translucency, in all groups significant difference was detected between sintering groups and the mean TP values were always higher in HS groups and the difference showed an increase from enamel to body. Molecular diversity among layers was detected according to SEM images however, the difference between the grains was not clearly determined (Figure 2).

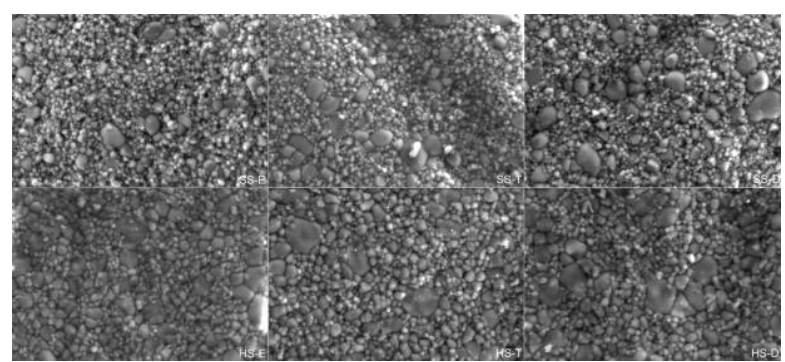

Figure 2. SEM images of the samples. Speed sintering enamel (SSE), speed sintering transition (SS-T), speed sintering dentin (SS-D), high speed sintering enamel (HS-E), high speed sintering transition (HS-T), high speed sintering dentin (HS-D).

\section{DISCUSSION}

According to the results of the study which compare the surface textures and optical properties, decreased dwelling time with the increased temperature would not have a significant effect on SR and CR of the zirconia, however the TP values were improved, so the first hypothesis was rejected.

The first mentioned topic would be the effect of high speed sintering protocol on mechanical properties of zirconia, since the specimens were sintered at a pre-heated furnace. Internal stresses are expected to occur as the material is subjected to sudden heat changes and these stresses must deteriorate the mechanical properties of the material. However, Ersoy et al. ${ }^{22}$ compared the flexural strength of different zirconia brands which were sintered at $1510^{\circ}$ for $120 \mathrm{~min}, 1540^{\circ}$ for 25 $\mathrm{min}$, and $1580^{\circ}$ for $10 \mathrm{~min}$ and mentioned that the highest flexural strength values for all brands were obtained at $1580^{\circ}$ for $10 \mathrm{~min}$ groups. The optical improvement of anatomic monolithic zirconia sintered at high speed parameter was detected in this research and this is due to the fact that the last temperature applied in the sintering process was higher.

In the present study, the SR of the different sintered monolithic zirconia was evaluated. The obtained data showed that there was no significant difference between groups. Although, increasing the sintering temperature reduce the SR via decreasing the gaps between zirconia molecules, the results obtained in this study did not support this situation and it is thought to be due to the short duration of high temperature application.

In this research, a SEM evaluation was used to determine the grain size changes. However, due to the molecular diversities, precise indication of the effect of the two different sintering processes on grain size has become complicated and needs quantitative analyses. For this reason, the interpretation of grain size changes in zirconium after different sintering protocols is based on the value of translucency.

In literature, the relation between grain size and translucency of zirconia mentioned in many research and indicated that the translucency was increased parallel with the increasing grain size. ${ }^{7,24}$ However, this optical improvement is not endless; the scattering effect of the zirconia increased when the grain size becomes equivalant to the wavelenght of the light $(400-700 \mathrm{~nm})$ and this make the material opaque. ${ }^{25}$ Besides, it can not be obtained an expansion of grain size at this level by the sintering process that have been prefered in the literature or adviced by the manufactures. Despite the short dwelling time in the HS group, higher 
molecular expansion is obtained due to the higher sintering temperature and as a result much translucent material is formed. This result emphesises that the sintering temperature is the major determinant for the grain size.

According to the results of recent study, monolithic zirconia became more translucent in HS group and the most translucent part was identified as the body part of the multi-layered zirconia which is darkest region to mimic the dentinal part of the tooth. Such a result may be attributed to the increment of the zirconia grain caused by the higher sintering temperature. While the higher TP may be a positive factor to meet aesthetic expectations, no matter which sintering parameter is preferred, there is no change in the $\mathrm{CR}$ of monolithic zirconia. For this reason, the prosthetic treatment on anterior region to fulfillment of the aesthetic expectation, must be considered carrefully.

The limitation of this study is the performing the tests on only one zirconia brand. The results may not be convenient for other commercial products with different grain sizes, different content, and different manufacturers. Furthermore, each manufacturer may recommend a different sintering parameter for its product.

\section{CONCLUSIONS}

According to the results of the study within the limitations, it can be summarized that:

Time-saving sintering process made the zirconia much translucent.

Although sintering process carried out in reverse, no adverse effect is caused on optical properties of zirconia.

\section{ACKNOWLEDGEMENTS}

None.

\section{CONFLICTS OF INTEREST}

The authors have no declared financial interests in any company manufacturing the types of products mentioned in this article.

\section{Hızlı Sinterlemenin Çok-Katmanlı Monolitik Zirkonya} Üzerine Etkisi

$\ddot{O} Z$

Amaç: Diş hekimliğinde, koltukta geçirilen sürenin kısaltılması adına farklı ürünler geliştirilmektedir fakat bu ürünlerin birbiriyle olan etkileşimleri daha ileri araştırmalara ihtiyaç duymaktadır. Bu çalışma, monolitik çok-katmanlı zirkonyanın yüzey pürüzlülüğ̈̈ (SR), translüsentlik parametresi (TP) ve kontrast oranı (CR) üzerine iki farklı klsa süreli sinterleme protokolünün etkilerini incelemeyi amaçlamaktadır. Gereç ve Yöntemler: 20 adet 10x10x1 mm boyutlarında monolitik çok-katmanl zirkonya örnekler hazırlanıp, iki farklı sinterleme grubuna ayrldı (1510 0C' de $30 \mathrm{dk}$ ' lı hizl sinterleme grubu, 1580 0C' de $10 \mathrm{dk}$ ' lık yüksek hizlı sinterleme grubu) ve SEM analizleri gerçekleştirildi. Profilometre yardımıyla yüzey pürüzlülük değerleri ölçülürken, spektrofotometre kullanılarak optik özellikleri tespit edildi. Elde edilen verilerin analizinde Wilcoxen testi kullanıldı ve anlamlılık düzeyi 0,05 olarak ayarlandı. Bulgular: Gruplar arasında yüzey pürüzlülük değerleri ve kontrast oranları bakımından istatistiksel olarak önemli bir farklılık tespit edilmedi. Sinterleme grupları arasinda, monolitik çok-katmanlı zirkonya örneklerin bütün katmanlarının translusentlik değerleri arasındaki fark istatistiksel olarak önemli olarak tespit edildi $(p<.05)$. Sonuçlar: Yüksek hızl sinterleme parametreleri, monolitik çok-katmanlı zirkonya üzerinde kabul edilebilir optik özelliklerle birlikte umut verici etkilere sahiptir. Farkl içerikleri nedeniyle, farklı katmanların kontrast oranı ve translusentlik parametreleri farkl reaksiyonlar gösterebilmektedir ve bu farklıliklar tedavi planlamasinda dikkate alınmalıdır. Anahtar Kelimeler: Zirkonya, sinterleme, kontrast orani, translusensi.

\section{REFERENCES}

1. John M. Evolution of dental ceramic in the twentieth century. J prosthet Dent 2001;85:61-66.

2. Rosenbulm. A review of all-ceramic restorations. JADA 128:297-307.

3. Oh GJ, Lee K, Lee DJ, et al. Effect of metal chloride solutions on coloration and biaxial flexural strength of yttria-stabilized zirconia. Met Mater Int 2012;18:805812.

4. Kirmali O, Kapdan A, Kustarci A, Er K. Veneer Ceramic to Y-TZP Bonding : Comparison of Different. J Prosthodont 2016;25:324-329.

5. Heintze SD, Rousson V. Survival of zirconia- and metal-supported fixed dental prostheses: a systematic review. Int J Prosthodont 2010;23:493-502.

6. Sailer I, Fehér A, Filser F, Gauckler LJ, Lüthy H, Hämmerle CHF. Five-year clinical results of zirconia 
frameworks for posterior fixed partial dentures. Int $\mathbf{J}$ Prosthodont 2007;20:383-388.

7. Stawarczyk B, Mutlu Ö, Hallmann L, Ender A, Mehl

A, Hammerlet CHF. The effect of zirconia sintering temperature on flexural strength, grain size, and contrast ratio. Clin Oral Investig 2013;17:269-274.

8. Sulaiman T A, Abdulmajeed A A, Donovan T A, Vallittu P K, Narhi T O, Lassila L V. The effect of staining and vacuum sintering on optical and mechanical properties of partially and fully stabilized monolithic zirconia. Dent Mater J 2015;34:605-610.

9. Denry I, Kelly JR. Emerging ceramic-based materials for dentistry. J Dent Res 2014;93:1235-1242.

10. Ebeid K, Wille S, Hamdy A, Salah T, El-Etreby A, Kern M. Effect of changes in sintering parameters on monolithic translucent zirconia. Dent Mater 2014;30:419-424.

11. Sulaiman TA, Abdulmajeed AA, Donovan TE, et al. Optical properties and light irradiance of monolithic zirconia at variable thicknesses. Dent Mater 2015;31:1180-1187.

12. Jiang L, Liao Y, Wan Q, Li W. Effects of sintering temperature and particle size on the translucency of zirconium dioxide dental ceramic. J Mater Sci Mater Med 2011;22:2429-2435.

13. Shah K, Holloway JA, Denry IL. Effect of Coloring with Various Metal Oxides on the Microstructure, Color, and Flexural Strength of 3Y-TZP. J Biomed Mater Res - Part B Appl Biomater 2008;87:329-337.

14. Tuncel I, Eroglu E, Sari T, Usumez A. The effect of coloring liquids on the translucency of zirconia framework. J Adv Prosthodont 2013;5:448-451.

15. Kim H, Kim S. Comparison of the optical properties of pre- colored dental monolithic zirconia ceramics sintered in a conventional furnace versus a microwave oven. J Adv Prosthodont 2017;9:394-401.
16. Brodbelt RHW, O’brien WJ, Fan PL. Translucency of Dental Porcelains. J Dent Res 1980;59:70-75.

17. Stawarczyk B, Emslander A, Roos M, Sener B, Noack F, Keul C. Zirconia ceramics, their contrast ratio and grain size depending on sintering parameters. Dent Mater J 2014;33:591-598.

18. Kim M-J, Ahn J-S, Kim J-H, Kim H-Y, Kim W-C. Effects of the sintering conditions of dental zirconia ceramics on the grain size and translucency. J Adv Prosthodont 2013;5:161-166.

19. Chen IW, Wang XH. Sintering dense nanocrystalline ceramics without final-stage grain growth. Nature 2000;404:168-171.

20. Wang H, Xiong F, Zhenhua L. Influence of varied surface texture of dentin porcelain on optical properties of porcelain specimens. J Prosthet Dent 2011;105:242248.

21. Obregon A, Googkind RJ, Schwabacher WB. Effects of opaque and porcelain surface texture on the color of ceramometal restorations. Res Educ 1981;46:330-340.

22. Ersoy NM, Aydoğdu HM, Değirmenci BÜ, Çökük $\mathrm{N}$, Sevimay M. The effects of sintering temperature and duration on the flexural strength and grain size of zirconia. Acta Biomater Odontol Scand 2015;1:43-50.

23. Johnston WM, Ma T, Kienle BH. Translucency parameter of colorants for maxillofacial prostheses. Int J Prosthodont 1995;8:79-86.

24. Vichi A, Sedda M, Fabian Fonzar R, Carrabba M, Ferrari M. Comparison of contrast ratio, translucency parameter, and flexural strength of traditional and "augmented translucency" zirconia for CEREC CAD/CAM system. J Esthet Restor Dent 2016;28:32-39. 25.Zhang Y. Making yttria-stabilized tetragonal zirconia translucent. Dent Mater 2014;30:1195-1203. 